\title{
AN INCONSISTENCY IN FRIEDMAN'S PRESIDENTIAL ADDRESS TO THE AEA: A CORRECTION
}

BY

JAMES FORDER

In James Forder (2016) I drew attention to an error in Milton Friedman (1968). I noted that, concerning the initial effects of a policy-induced increase in the rate of growth of the money supply, Friedman wrote, "Producers will tend to react to the initial expansion in aggregate demand by increasing output, employees by working longer hours, and the unemployed, by taking jobs now offered at former nominal wages. This much is pretty standard doctrine" (p. 10). He continued by discussing the later effects on the basis that wages had risen. That is inconsistent because he had said the changes were taking place at "former" wages.

That is correct. However, in a footnote I remarked that Daniel Hammond had suggested I look at drafts of the lecture at the Hoover Institution, and I said that the earliest, dated July 1967 (Hoover Archive, Milton Friedman collection, Box 49, folder 10), contained the same passage, except that "former nominal wages" was simply "former wages."

Indeed, the lines just quoted are materially the same in that draft, but the following discussion is not. There, Friedman continued by saying,

\begin{abstract}
But now let the new rate of monetary growth continue. What will happen? Though nominal income will continue to rise more rapidly than before the monetary change, an increasing part of the rise will take the form of a rise in prices. Why? With demand stronger than anticipated when initial prices were set and output higher, producers will have an incentive to raise their prices and will be able to do so; the strong demand for labor will lead to the bidding up of wages, and so on down the line. (pp. 8-9)
\end{abstract}

This is still not quite satisfactory, since Friedman has presumed an increased rate of growth of the money supply continues, whereas the initial effect would have been brought about by a one-time increase in the quantity of money. But he clearly avoids the inconsistency that appeared in the final version of the address.

My error makes no difference to the main argument of my paper, since that concerned what was said in the final version. But it does mean that Daniel Hammond's advice was even more valuable than it first appeared, and reveals that the clear error came into Friedman's Presidential Address as a result of a revision of the earlier draft.

James Forder, Balliol College, Oxford, james.forder@balliol.ox.ac.uk.

ISSN 1053-8372 print; ISSN 1469-9656 online/17/04000599-600 @ The History of Economics Society, 2017 doi:10.1017/S1053837217000050 


\section{REFERENCES}

Forder, James. 2016. "A Neglected Inconsistency in Milton Friedman's AEA Presidential Address." Journal of the History of Economic Thought 38 (1): 105-112.

Friedman, Milton. 1968. "The Role of Monetary Policy.” American Economic Review LVIII (1): 1-17. 